\title{
Efektivitas Kinerja Dosen Stie Mujahidin Tolitoli Dalam Menggunakan Metode Pembelajaran Daring (Studi Kasus Pada Stie Mujahidin Tolitoli)
}

\section{Performance Effectiveness Of Lecturers Of Stie Mujahidin Tolitoli In Using The Online Learning Method (Case Study At Stie Mujahidin Tolitoli)}

\author{
Suparman $^{1}$, Nurliana ${ }^{2}$ \\ Program Studi Manajemen, Sekolah Tinggi Ilmu Ekonomi Mujahidin \\ 1'(suparman@stiemujahidin.ac.id) \\ 22(kjliana14@gmail.com)
}

\begin{abstract}
ABSTRAK
Metode pembelajaran daring adalah metode pembelajaran yang terbilang baru bagi Kampus STIE Mujahidin Tolitoli, perlu penyesuaian. Namun, bukan berarti mustahil untuk dilakukan. Penelitian ini bertujuan untuk mengetahui apakah kinerja dosen STIE Mujahidin Tolitoli sudah efektif dalam menggunakan metode pembelajaran daring. Penelitian ini menggunakan desain penelitian kualitatif. Sumber data berupa data primer, yaitu data yang diperoleh melalui obervasi, wawancara mendalam serta dokumentasi yang berkaitan dengan penelitian ini. Teknik analisis data yang digunakan adalah reduksi data, penyajian data (display data), penarikan kesimpulan dan verifikasi teknik triangulasi. hasil penelitian dan pembahasan dapat disimpulkan bahwa kinerja dosen kurang efektif dalam menggunakan metode pembelajaran daring. Hasil penelitian menunjukkan indikator keefektivitasan tidak tercapai dengan maksimal. Dosen harus memperkaya diri dengan $3 \mathrm{M}$, yakni media, metode dan materi. Faktor penunjang metode pembelajaran daring juga harus ditingkatkan (sarana dan prasarana, aturan yang dibuat oleh kampus, peningkatan kompetensi dosen, serta komunikasi yang efektif dan efisien antara dosen dan mahasiswa).
\end{abstract}

Kata Kunci : Kinerja dosen, metode pembelajaran daring

\begin{abstract}
The online learning method is a relatively new learning method for the STIE Mujahidin Tolitoli Campus. It needs adjustments. However, that does not mean it is impossible to do. This study aims to determine whether the lecturers' performance of STIE Mujahidin Tolitoli has been effective in using online learning methods. This study uses a qualitative research design. The data source is primary data, namely data obtained through observations, in-depth interviews, and documentation related to this research. The data analysis technique used was data reduction, data presentation (data display), drawing conclusions, and verification of the triangulation technique. The results of research and discussion can be concluded that the performance of lecturers is less effective in using online learning methods. The results showed that the effectiveness indicator was not maximally achieved. Lecturers must enrich themselves with 3M, namely media, methods and materials. Supporting factors for online learning methods must also be improved (facilities and infrastructure, rules made by the campus, increased lecturer competence, and effective and efficient communication between lecturers, and students).
\end{abstract}

Keywords: Lecturer performance, online learning method

\section{PENDAHULUAN}

Dunia Pendidikan telah mengalami kemajuan pesat seiring dengan kemajuan Teknologi Informasi. Akibatnya, metode pendidikan lama atau biasa disebut dengan konvensional dirasakan menjadi kurang efektif karena terbentur masalah ruang dan waktu. Teknologi Informasi menawarkan metode pendidikan baru yang dinamakan metode E-Learning. Sistem pembelajaran elektronik atau e-pembelajaran adalah cara baru dalam proses belajar mengajar. $E$ learning merupakan pengajaran dan pembelajaran didukung dan dikembangkan oleh media digital, dan juga merupakan 
salah satu bentuk dari konsep belajar jarak jauh.

Pandemi Corona Virus Diseases (Covid-19) yang berasal dari kota Wuhan (China), mulai masuk dan menyebar di Indonesia pada awal bulan Maret 2020, hal ini mengakibatkan perubahan yang signifikan di segala aspek kehidupan. Penyebaran virus ini sangat cepat sehingga pemerintah meminta masyarakat untuk mengurangi aktivitas di luar rumah (Sosial Distancing,dan Physical Distancing). Kemudian Mentri Pendidikan dan Kebudayaan mengeluarkan surat edarannya tentang pembelajaran daring dan bekerja dari rumah dalam rangka pencegahan penyebaran Corona Virus Disease (Covid-19).

Menyikapi intruksi tersebut, Ketua STIE Mujahidin Tolitoli akhirnya mengeluarkan pengumuman Nomor: 262/STIE-M/III/2020, pada Tanggal 17 Maret 2020, yang menyatakan bahwa perkuliahan akan dilaksanakan secara daring dan akan ditinjau kembali sesuai dengan perkembangan dan kebijakan pemerintah terkait Covid-19 tersebut. Berdasarkan hal tersebut, Penulis berpikir bahwa perlu melakukan kajian tentang efektivitas kinerja dosen dalam menggunakan metode pembelajaran daring.

Tujuan Penelitian ini adalah untuk mengetahui apakah kinerja dosen STIE Mujahidin Tolitoli sudah efektif dalam menggunakan metode pembelajaran daring.

\section{Pembelajaran Metode Daring}

E-Learning merupakan pengajaran dan pembelajaran didukung dan dikembangkan oleh media digital, dan juga merupakan salah satu bentuk dari konsep belajar jarak jauh. E-Learning sangat membantu dalam aktivitas belajar dan mengajar di perguruan tinggi karena peserta didik sekarang yang merupakan generasi milenial (y) dan generasi $\mathrm{Z}$ sangat menyukai sesuatu yang mudah didapat dan diakses di mana saja dan kapan saja menggunakan gadget.

Menurut Yazdi (2012:143) E-Learning merupakan sebuah sistem pengajaran dan pembelajaran sebagai aplikasi teknologi informasi yang diterapkan di dunia pendidikan dalam bentuk learning. Hal ini membuat peserta didik tidak perlu bertatap muka langsung dengan dosen. E-Learning dapat mempersingkat target jadwal pembelajaran, paperless.

Istilah daring merupakan akronim dari "dalam jaringan". Jadi perkuliahan daring adalah metode pembelajaran online atau dilakukan melalui jaringan internet. Sistem perkuliahan daring ini dikembangkan oleh Kementerian Pendidikan dan Kebudayaan Republik Indonesia melalui Program Kuliah Daring Indonesia Terbuka dan Terpadu (KDITT).

Menurut Siahan dalam Hakim (2016:1) ada tiga fungsi e-Learning terhadap kegiatan pembelajaran secara konvensional yaitu:

1. Suplemen (tambahan), peserta didik memiliki kebebasan memilih untuk mengakses materi perkuliahan. Sekalipun sifatnya opsional, peserta didik yang memanfaatkan e-learning akan memiliki tambahan pengetahuan atau wawasan.

2. Komponen (pelengkap), sebagai tambahan belajar peserta didik jika materi yang disampaikan di kelas sulit untuk dipahami.

3. Subtitusi (pengganti), apabila e-learning dilakukan sebagai pengganti model kegiatan belajar. Ada tiga model pembelajaran yang dapat dipilih, yakni: sepenuhnya secara tatap muka (konvensional), sebagian secara tata muka dan sebagian lagi melalui internet, atau sepenuhnya melalui internet.

\section{Efektivitas}

Menurut kamus besar bahasa Indonesia (2008:352) Efektivitas adalah keberhasilan suatu usaha, tindakan. Dalam bahasa 
Belanda effectief memiliki makna berhasil guna.

Indrawijaya dan Adam Ibrahim (2010:129) mengatakan bahwa "Efektivitas adalah suatu ukuran yang menyatakan seberapa jauh target (kuantitas, kualitas, dan waktu) yang telah dicapai, yang mempunyai pengaruh serta membawa hasil guna mencapai suatu keberhasilan dalam suatu kegiatan". Efektivitas menunjukan keberhasilan dari segi tercapai tidaknya sasaran yang telah ditetapkan. Jika hasil kegiatan semakin mendekati sasaran, berarti makin tinggi efektivitasnya.

Menurut Stephen P. Robbins dalam Moh Pabundu Tika (2010:129) mendefinisikan efektivitas itu sebagai tingkat pencapaian organisasi jangka pendek dan jangka panjang. Artinya, suatu efektivitas dapat dilihat dari tingkat pencapaian organisasi di mana makin besar presentase target yang dicapai, makin tinggi efektivitasnya. Sedangkan Efektivitas pembelajaran merupakan keberhasilan interaksi dosen dan mahasiswa dalam mewujudkan harapan masyarakat yang di mana keberadaan dosen sebagai sosok yang berperan penting dalam keberhasilan proses pembelajaran (Surachim, 2016:3).

\section{Kinerja Dosen}

Kinerja adalah keberhasilan seorang karyawan didalam menyelesaikan pekerjaan, Rivai (2011:309) mendefinisikan kinerja sebagai perilaku nyata yang ditampilkan setiap orang sebagai prestasi kerja yang dihasilkan oleh karyawan sesuai dengan perannya dalam perusahaan (organisasi). Sedangkan menurut Simanjuntak (2005:1) kinerja adalah tingkat pencapaian hasil atau pelaksanaan tugas tertentu. Berdasarkan definisi tersebut dapat disimpulkan bahwa kinerja dosen adalah hasil kerja yang dicapai oleh dosen dalam kurun waktu tertentu sesuai dengan wewenang dan tanggung jawabnya sebagai tenaga fungsional akademik. Kinerja dosen merupakan salahsatu faktor penentu keberhasilan proses belajar mengajar di perguruan tinggi. Terdapat hubungan yang erat antara kinerja perseorangan dengan kinerja perusahaan. Dari pertanyataan tersebut menunjukkan bahwa apabila kinerja dosen baik, maka kinerja perguruan tinggi juga akan menjadi baik.

Di dalam pasal 8 dan 10 UU RI No. 14 Tahun 2005 tentang guru dan dosen yang berbunyi "Guru wajib memiliki kualifikasi akademik (Pasal 8), kompetensi, sertifikat pendidik, sehat jasmani dan rohani, serta memiliki kemampuan untuk mewujudkan tujuan pendidikan nasional. Kompetensi yang dimaksud dalam pasal 8 adalah kompetensi pedagogik, kepribadian, sosial, dan profesional yang diperoleh melalui pendididkan profesi (Pasal 10).

1. Kompetensi Pedagogik, adalah kemampuan mengolah pembelajaran peserta didik

2. Kompetensi Kepribadian, adalah kemampuan berkepribadian yang baik, berakhlak mulia, arif, dan berwibawa serta menjadi teladan bagi peserta didik

3. Kompetensi Sosial adalah, kemampuan guru/dosen untuk berkomunikasi dan berinteraksi secara efektif dan efisien dengan peserta didik.

4. Kompetensi profesional, adalah kemampuan penguasaan materi kuliah secara luas dan mendalam.

\section{METODE}

Dalam penelitian ini menggunakan metode penelitian kualitatif dengan pendekatan deskriptif. Menurut Sugiyono (2017:15) penelitian kualitatif adalah suatu metode penelitian yang berlandaskan pada filsafat postpositivisme, digunakan untuk meneliti pada kondisi objek yang alamiah di mana peneliti adalah sebagai instrument kunci. Penelitian kualitatif menggambarkan keadaan sebenarnya tentang apa yang terdapat pada saat penelitian dengan cara mengumpulkan data, mengklasifikasikan, serta 
menganalisanya sehingga diperoleh perumusan analisa terhadap masalah yang dihadapi.

Lokasi penelitian dilaksanakan di Sekolah Tinggi Ilmu Ekonomi (STIE) Mujahidin Tolitoli yang bertempat di jalan Samratulangi No.51 Kelurahan Tuweley. Dengan waktu penelitian yaitu selama 3 bulan dari bulan Juli sampai September 2020.

Teknik pengumpulan data merupakan langkah yang paling strategis dalam penelitian, karena tujuan utama dari penelitian adalah mendapatkan data dengan cara Pengamatan (observasi), Wawancara dan Dokumentasi. Teknik analisis data yang digunakan dalam penelitian ini adalah analisis kualitatif yang bersifat deskriptif, yaitu data yang sudah terkumpul akan diseleksi, memilihmilih menjadi satuan yang dapat dikelola, mencari dan menemukan apa yang penting dan apa yang dipelajari, dan membuat kesimpulan sehingga mudah dipahami orang lain (Lexy, 2002:248). Miles dan Huberman dalam Sugiyono (2017:114), mengemukakan bahwa aktivitas dalam analisis data kualitatif dilakukan secara interaktif dan berlangsung terus-menerus sampai tuntas, hingga datanya jenuh.

Proses triangulasi itu dilakukan terus menerus sepanjang proses mengumpulkan data dan analisis data, sampai suatu saat peneliti yakin bahwa sudah tidak ada lagi perbedaan-perbedaan dan tidak ada lagi yang perlu dikonfirmasi kepada informan. Triangulasi juga dapat dilakukan dengan menguji pemahaman peneliti dengan pemahaman informan tentang hal-hal yang diinformasikan oleh informan kepada peneliti.

\section{HASIL DAN PEMBAHASAN}

Hasil penelitian ini didapatkan melalui wawancara mendalam yang dilakukan oleh peneliti pada kurun waktu bulan September 2020. Wawancara dilakukan pada beberapa informan sesuai ketentuan dalam penelitian ini, yakni unsur ketua serta beberapa dosen dan mahasiswa STIE Mujahidin Tolitoli.

\section{Kesiapan Kampus Dalam \\ Menggunakan Metode Pembelajaran Daring Pada Masa Pandemi.}

Metode pembelajaran daring adalah hal baru bagi kampus STIE Mujahidin Tolitoli, sebab selama ini sistem akademik hanya melakukan perkuliahan metode konvensional. Maka dari pada itu kampus STIE Mujahidin belum memiliki standar regulasi yang khusus untuk perkuliahan pada masa pandemi tersebut.

Pembelajaran metode daring ini adalah hal baru, maka perlu dilakukan pelatihan kepada dosen terkait metode pembelajaran daring. Kampus STIE Mujahidin Tolitoli telah melakukan pelatihan satu kali dalam bentuk workshop pada awal perkuliahan kelas daring dimulai, pelatihan ini diperuntukkan untuk dosen. Kampus melakukan persiapan dengan melakukan pelatihan untuk dosen meski hanya dilakukan sekali saja. Namun, diharapkan dosen yang akan mengembangkan pemahamannya sendiri serta akan mengajarkan dan mengarahkan mahasiswanya terkait penggunaan media pembelajaran tersebut.

\section{Kesiapan dan Kendala Dosen Dalam Menggunakan Metode Pembelajaran Daring}

Kesiapan kemampuan menggunakan media pembelajaran juga sangat diperlukan, apalagi kampus STIE Mujahidin Tolitoli sudah membuat pelatihan terkait cara penggunaan media pembelajaran daring. Dosen STIE Mujahidin Tolitoli dalam proses mempelajari dan terus melakukan adaptasi dengan media yang digunakan dalam metode daring tersebut.

Kendalanya adalah terkait kurang paham dengan cara penggunaan media atau metode yang digunakan saat perkuliahan daring serta jaringan dan kuota internet.

$\begin{array}{lcr}\text { Kesiapan dan Kendala } & \text { Mahasiswa } \\ \text { Dalam } & \text { Menggunakan } & \text { Metode } \\ \text { Pembelajaran Daring } & \end{array}$


Mahasiswa yang notabenenya adalah generasi $Z$, yang sudah familiar dengan teknologi, seharusnya bisa lebih siap perihal penggunaan media pembelajaran dan penyesuaian diri dengan metode pembelajaran daring. Kesiapan mental juga diperlukan, sebab dalam situasi di mana orang-orang diminta untuk melakukan aksi jaga jarak, pemerintah dalam keadaan sedang berusaha mengatasi pandemi, mereka juga harus fokus dalam menerima materi. Syukurnya kabupaten Tolitoli memiliki angka kecil terdampak Covid-19, sehingga rasa waspada tidak sebesar kota lain yang terdampak Covid-19 dengan skala besar.

pembelajaran di semester genap 2020 mahasiswa masih menggunakan kuota internet pribadi, sehingga banyak yang mengalami kesulitan terhadap tidak memadainya kuota internet yang mereka miliki. Beberapa informan juga mengakui bahwa kesulitan mereka terdapat pada tingkat kepahaman terhadap materi serta metode yang dosen gunakan, hal itu akan peneliti bahas di sub bab selanjutnya.

\section{Metode Yang Dosen Gunakan Dalam Pembelajaran Daring}

Teori kognitivisme menjadi acuan dalam mengembangkan dan mengorganisasi materi serta aktivitas pembelajaran. Mengacu pada teori kognitivisme, maka materi dan aktivitas pembelajaran didesain agar pembelajaran memiliki makna bagi diri peserta didik, dan menumbuhkan partisipasi aktif dalam proses pembelajaran. Teori konstruktivisme menjadi inspirasi dalam mengembangkan bahan ajar, tugas dan diskusi agar mengandung muatanmuatan yang bersifat kontekstual dan memberikan pengalaman belajar peserta didik. Serta memperhatikan proses pengajaran dimulai dari persiapan perkuliahan, proses perkuliahan, respon mahasiswa dan evaluasi perkuliahan.

\section{Kinerja Dosen STIE Mujahidin Dalam Menggunakan Metode Pembelajaran Daring}

Hasil wawancara dengan informan dari unsur dosen, peneliti mendapatkan data bahwa sasaran dan output selama perkuliahan online ini memang agak sulit dicapai sepenuhnya. Pada semester genap tahun 2020 bisa simpulkan bahwa kinerja dosen kurang baik dalam menggunakan metode daring, karena banyak keluhan mahasiswa yang berkaitan dengan tidak aktifnya proses pembelajaran. Saat memasuki semester ganjil perubahannya sudah luar biasa.

\section{KESIMPULAN DAN SARAN}

Berdasarkan pembahasan tersebut dengan indikator dari sisi keberhasilan program, ternyata beberapa dosen belum paham cara penggunaan media pembelajaran, kemudian dari sisi keberhasilan sasaran, mahasiswa sudah mampu melakukan perkuliahan daring meski banyak kendala yang dihadapi, dari sisi kepuasan terhadap program, merasa bahwa metode yang digunakan dosen monoton dan membosankan, serta dan sisi pencapaian tujuan menyeluruh, mahasiswa kurang paham dengan materi yang diberikan. Maka dapat disimpulkan bahwa kinerja dosen STIE Mujahidin Tolitoli dalam menggunakan metode pembelajaran daring 'kurang efektif'.

Diharapkan agar kampus dapat memperhatikan perangkat-perangkat penunjangnya, seperti pemaksimalan akses jaringan (WIFI) pembuatan LMS (Learning Manajemen System), SOP Pembelajaran daring panduan pembelajarn daring, pelatihan peningkatan kualifikasi dan kompetensi bagi dosen.

Diharapkan dosen menguasai media pembelajaran daring dengn meningkatkan kemampuan penguasaan teknologi. Selin itu, diharapkan dosen menggunakan metode pembelajaran daring yang lebih efektif, dosen harus bisa menyusun strategi pembelajaran (instructional strategis) daring, memperkaya diri dengan berbagai ide kreatif, dan mendesain aktivitas 
pembelajaran yang variatif, tidak hanya bertumpu pada video konferensi.

Diharapkan mahasiswa dapat membenahi kesiapan belajar mandiri, mahasiswa harus terbuka dengan metode pembelajaran daring dan harus ikut serta dalam perkembangan zaman jangan sampai gagap teknologi apalagi menolak pembelajaran metode daring.

\section{UCAPAN TERIMAKASIH}

Penulis mengucapkan terima kasih dan penghargaan yang setinggi-tingginya kepada kedua orang tua peneliti, Kepada Drs.H.M. Natsir Hi. Mallu, MM selaku Ketua STIE Mujahidin Tolitoli dan Seluruh Dosen dan Staf STIE Mujahidin Tolitoli.

\section{DAFTAR PUSTAKA}

Hakim A, B. 2016. Efektivitas Penggunaan E-Learning Moodle, Google Classroom dan Edmodo. Stimik Esq. Vol. 2 No. 1-4

Indrawijaya dan Ibrahim, Adam. 2010. Konsep Perilaku dan Budaya Organisasi. Bandung: Refika Aditama.

Kamus Besar Bahasa Indonesia. 2008. Pengertian Efektivitas.

Lexy, J Moloong. 2002. Metode Penelitian Kualitatif. Bandung: Remaja Rosdakarya.

Moh. Pabundu Tika, 2010, Budaya Organisasi dan Peningkatan Kinerja. Perusahaan, cetakan kedua, Penerbit : Bumi Aksara, Jakarta.

Rivai, Vethzal dan Basri. 2011. Performance Appraisal: Sistem Yang Tepat Untuk Menilai Kinerja Karyawan dan Meningkatkan Daya Saing Perusahaan. Jakarta: PT Raja Grafindo Persada.
Simanjuntak. 2005. Manajemen Dan Evaluasi Kinerja. Jakarta: Fakultas Ekonomi.

Sugiyono. 2017. Metode Penelitian Kuantitatif, Kualitatif, dan R \& D. Bandung: Alfabeta.

Surachim D. 2016. Efektivitas Pembelajaran Pola Pendidikan Sistem Ganda. Bandung: Alfabeta.

Undang-undang Republik Indonesia Nomor 14 Tahun 2005 Tentang Guru dan Dosen. 2005. Jakarta: Departemen Mendikbud Republik Indonesia.

Yazdi, M. 2012. E-Learning Sebagai Media Pembelajaran Interaktif Berbasis Teknologi Informasi. Jurnal Ilmiah Foristek. Vol. 2 No. 1. 